\title{
A new nano-ZnO/perlite as an efficient catalyst for catalytic ozonation of azo dye
}

\author{
Soheila Shokrollahzadeh ${ }^{\dagger}$, Masoud Abassi, Maryam Ranjbar \\ Department of Chemical Technologies, Iranian Research Organization for Science and Technology (IROST), P.O. Box 33535-111, Tehran, Iran
}

\begin{abstract}
In this investigation, nano $\mathrm{ZnO}$ was sonochemically synthesized by a novel method using a methionine precursor. A narrow size distribution $(41-50 \mathrm{~nm})$ of nano $\mathrm{ZnO}$ was achieved that was immobilized on perlite and applied as a catalyst in catalytic ozonation. The catalyst was characterized by fourier transform infrared spectroscopy, BET surface area, and field emission scanning electron microscope. The ozonation of recalcitrant Remazol black 5 (RB5) di-azo dye solution by means of the synthesized catalyst was investigated in a bubble column slurry reactor. The influence of $\mathrm{pH}$ values $(7,9,11)$, catalyst dosage $\left(8,12,15,20 \mathrm{~g} \mathrm{~L}^{-1}\right)$ and reaction time $(10,20,30,60 \mathrm{~min})$ was investigated. Although the dye color was completely removed by single ozonation at a higher reaction time, the applied nanocatalyst improved the dye declorination kinetics. Also, the degradation of the hazardous aromatic fraction of the dye was enhanced five-times by catalytic ozonation at a low reaction time (10 min) and a neutral $\mathrm{pH}$. The second-order kinetics was best fitted in terms of both RB5 color and its aromatic fraction removal. The total organic carbon analysis indicated a significant improvement in the mineralization of RB5 by catalytic ozonation using the nano- $\mathrm{ZnO} /$ perlite catalyst.
\end{abstract}

Keywords: Catalytic ozonation, Kinetics, Mineralization, Nano-ZnO/perlite catalyst, Remazol black 5

\section{Introduction}

Textile industries generate large amounts of wastewater with intense color and total organic carbon (TOC). The removal of textile dyes from wastewater is important due to its interference in the photochemical activities in aquatic systems. They also possess toxic, carcinogenic, and genetic mutation properties. Azo dyes, including Remazol black 5 (RB5), are known for their double bond nitrogen $(-\mathrm{N}=\mathrm{N}-)$. They are the most widely used dyes in the textile industry, constituting more than half of all textile dyes [1].

Several physical methods such as adsorption [2], chemical [3], and biological methods [4] have been investigated in the literature for the removal of dye from water. The advanced oxidation process (AOP) is a promising method for treating low-biodegradable hazardous pollutants in wastewater. AOPs produce powerful reactive $\mathrm{OH}$ radicals by the decomposition of ozone, which unselectively attack the organic pollutants and refractory molecules to mineralize them. Ozonation is a promising method to decolorize dye contaminated wastewater and degrade organic pollutants. The catalytic ozonation process (COP), in which a heterogeneous and homogeneous catalyst combines with ozone,

This is an Open Access article distributed under the terms of the Creative Commons Attribution Non-Commercial License (http://creativecommons.org/licenses/by-nc/3.0/) which permits unrestricted non-commercial use, distribution, and reproduction in any medium, provided the original work is properly cited.

Copyright (C) 2019 Korean Society of Environmental Engineers has been developed for overcoming the limitations of ozone [3, 5]. Heterogeneous catalytic ozonation has gained particular attention compared to homogeneous catalytic ozonation due to its simple catalyst separation, higher rate of dye removal, and cleaner procedure. Many metal oxides such as $\mathrm{TiO}_{2}$ [6], $\mathrm{Fe}_{2} \mathrm{O}_{3} / \mathrm{Al}_{2} \mathrm{O}_{3}$ [7], and nanomaterials such as $\mathrm{Pt} /$ carbon nanotube [8] have been studied in heterocatalyst/ozonation processes for the removal of oxalic acid. In addition, other catalysts have been used for the removal of different organic materials in catalytic ozonation: alumina for treating 2-chlorophenol [9]; biochar for phenol removal [10]; nano size $\mathrm{Co}_{3} \mathrm{O}_{4} / \mathrm{CeO}_{2}$ for phenol treatment[11]; $\mathrm{Au}-\mathrm{Bi}_{2} \mathrm{O}_{3}$ nanocatalyst for treating acid orange 10 [12]; NiO-CuO for removal of dichloroacetic acid [13]; zeolite ZSM-5 for removal of ibuprofen [14]; $\mathrm{MoO}_{3}$ nanocatalyst for decomposition of orange II dye [15]; and $\mathrm{MgO}$ nanocrystal for the degradation of reactive red 198 [3]. In recent years, some catalysts have been successfully exploited for the catalytic ozonation of RB5 dye in aqueous solution, including mesoporous carbon aerogel (MCA) supported copper oxide [1] and $\mathrm{CuS}$ [16]. Zinc oxide is a known catalyst and can be used in environmental remediation processes due to its high chemical stability, low toxicity, biocompatibility, high catalytic activity

Received September 10, 2018 Accepted November 10, 2018

${ }^{\dagger}$ Corresponding author

Email: shokrollahzadeh@irost.ir

Tel: +98-21-56276637 Fax: +98-21-56276265

ORCID: 0000-0001-8589-8304 
in catalytic ozonation [17], very low solubility, and low price. $\mathrm{ZnO}$ powder, as a catalyst, has been used in different particle sizes and shapes for the removal of organic materials [18-20]. $\mathrm{ZnO}$ has been synthesized by different methods: using a precursor [21], hydrothermal [22], sonochemical [23], and modified sol-gel [24]. The synthesis of $\mathrm{ZnO}$ on different supports has been previously reported; for example, dip-coating $\left(\mathrm{ZnO} / \mathrm{SnO}_{2}\right)$ [22], thermal evaporation ( $\mathrm{ZnO} /$ zeolite) [25], mixing ( $\mathrm{ZnO} /$ mordenite zeolite) [23], and impregnation ( $\mathrm{ZnO} /$ faujasite $\mathrm{X}$ zeolite) [26].

It is reported that the rate constant for catalytic ozonation using nano-sized catalyst is higher than larger sizes of the catalyst [17]. In this study, a novel $\mathrm{ZnO}$ nanocatalyst was sonochemically synthesized using a methionine ligand, to control the size distribution of the catalyst. Other ligands or precursors have been applied for the preparation of the $\mathrm{ZnO}$ catalyst [27-29]. However, the methionine is a bi-dentate ligand with two atoms ( $\mathrm{N}$ and O) for connecting the dipolar bond, and is an appropriate ligand for the synthesis of $\mathrm{ZnO}$. Perlite has been used as a natural, inert and cheap alumino-silicate as support, which provides a large surface area for the immobilization of $\mathrm{ZnO}$. The $\mathrm{Zn}$ (II) methionine complex $\left[\mathrm{ZnC}_{4} \mathrm{H}_{9} \mathrm{SNH}_{2} \mathrm{COOH}\right]$ was prepared via the sonochemical method and used as the precursor for impregnation of the expanded perlite to produce the $\mathrm{ZnO} /$ perlite nanocatalyst. The synthesized nano-ZnO/perlite was used for the catalytic ozonation of RB5 in a bubble column reactor. The influence of process parameters ( $\mathrm{pH}$, as-prepared catalyst dosage and reaction time) on the degradation efficiency of RB5 in aqueous solution has been also investigated. The degree of the mineralization of RB5 by catalytic ozonation was also compared to single ozonation.

\section{Materials and Methods}

\subsection{Materials}

Commercial perlite powder $\left[\mathrm{SiO}_{2}, \mathrm{Al}_{2} \mathrm{O}_{3}, \mathrm{Na}_{2} \mathrm{O}, \mathrm{K}_{2} \mathrm{O}, \mathrm{Fe}_{2} \mathrm{O}_{3}, \mathrm{MgO}\right.$, $\mathrm{CaO}$ ] was purchased from the Pars Company, Iran. The zinc nitrate tetrahydrate, methionine amino acid $\left[\mathrm{C}_{4} \mathrm{H}_{9} \mathrm{SNH}_{2} \mathrm{COOH}\right]$, hydrochloric acid $1 \mathrm{~N}$, sodium hydroxide $1 \mathrm{~N}$, all in analytical grade, were obtained from the Merck Company (Germany) and used without further purification. The RB5 with 99\% purity was purchased from the Sabet Alvan Co., Iran. Structurally, RB5 has two azo double bonds and a naphthalene ring in the middle of the molecule and two benzene rings (Fig. S1).

\subsection{Synthesis of the Zinc Methionine $\left[\mathrm{C}_{4} \mathrm{H}_{9} \mathrm{SNH}_{2} \mathrm{COOH}\right]$ Complex}

The sonochemical method was used to synthesize the $\left[\mathrm{C}_{4} \mathrm{H}_{9} \mathrm{SNH}_{2}\right.$ $\mathrm{COOH}$ ] complex, which is a simple, economical, environmentally safe and favorable method for the synthesis of nanostructures. Zinc nitrate tetrahydrate and methionine amino acid in a molar ratio of 1:2 was mixed in deionized water and kept under ultrasonic irradiation (Misonix sonicator S- 4000 model) at a $600 \mathrm{~W}$ power output for 20 min until the solution color turned light yellow. The complex was identified via Fourier transform infrared (FT-IR) spectroscopy.

\subsection{Synthesis of $\mathrm{ZnO} /$ Perlite Nanocatalyst}

The perlite powder (2 g) was agitated in $20 \mathrm{~cm}^{3} \mathrm{HCl} 1 \mathrm{~N}$ for
$5 \mathrm{~h}$ followed by centrifugation to achieve the modified (expanded) zeolite [30]. The solid phase was heated at $900^{\circ} \mathrm{C}$ for $4 \mathrm{~h}$ to increase the porosity, and the expanded perlite was achieved. Then, 50 $\mathrm{cm}^{3}$ of the synthesized zinc methionine $\left[\mathrm{ZnC}_{4} \mathrm{H}_{9} \mathrm{SNH}_{2} \mathrm{COOH}\right]$ solution was added slowly to expanded perlite powder and mixing was continued for $48 \mathrm{~h}$; then, it was centrifuged. The resulting gel was burnt under direct flame operation to remove the initial organic matter. According to the thermogeravimetric analysis and differential thermal analysis (TGA/DTA), the $\mathrm{ZnO}$ /perlite nanocatalyst was achieved by the calcination of the precipitate in a furnace at $650^{\circ} \mathrm{C}$ for $4 \mathrm{~h}$ to remove organic materials. The $\mathrm{ZnO} /$ perlite catalyst was washed with methanol (two times) and acetone to remove residual impurities and dried at $150^{\circ} \mathrm{C}$ for $3 \mathrm{~h}$.

\subsection{Ozonation and Catalytic Ozonation Procedure}

The ozonation and catalytic ozonation processes were investigated in a $1 \mathrm{~L}$ semi-batch bubble column slurry reactor. The ozone was continuously bubbled into a $250 \mathrm{~cm}^{3}$ RB5 dye solution (100 $\mathrm{mg} \mathrm{L}^{-1}$ ) for a pre-determined time. The ozone was generated from the air by an Ozomax OZO 1 VTTL ozone generator and continuously fed to the reactor through a sparger.

For the catalytic ozonation experiment, catalyst powder was added to the RB5 dye solution (100 $\mathrm{mg} \mathrm{L}^{-1}$ ) at a dosage of 20 $\mathrm{g} \mathrm{L}^{-1}$ before ozone injection, unless other values were stated. The influence of three parameters including the $\mathrm{pH}$ values $(7$, 9 , 11), catalyst dosage $\left(8,12,16,20 \mathrm{~g} \mathrm{~L}^{-1}\right)$ and reaction time $(10,20,30,60 \mathrm{~min})$ were investigated. The solution $\mathrm{pH}$ was adjusted to the desired values using $\mathrm{HCl}$ or $\mathrm{NaOH} 1 \mathrm{~N}$. At different time intervals of the ozonation process, $15 \mathrm{~cm}^{3}$ solutions were sampled for measuring the dye concentration and TOC. One $\mathrm{cm}^{3}$ of $0.1 \mathrm{~N}$ sodium thiosulfate solution was added to the sample simultaneously after sampling in order to prevent further oxidation with the dissolved ozone. To eliminate the effect of RB5 dye adsorption onto the nanocatalyst or RB5 direct oxidation by the catalyst, each experiment was repeated using the nanocatalyst without ozonation as a reference test. The experiments were performed at room temperature $\left(23 \pm 2^{\circ} \mathrm{C}\right)$. The ozone in the off-gas stream was quenched and destructed in a $2 \% \mathrm{KI}$ solution [31]. The ozone mass flow was considered constant at $1.533 \mathrm{~g} \mathrm{~h}^{-1}$ throughout the experiment. All the experiments were carried out three times and the average values are presented in this article.

\subsection{Analytical Methods}

FT-IR spectroscopy was carried out using a Philips PU 9624 spectrometer. The morphology and size of the synthesized nanocatalyst were determined by scanning electron microscopy (SEM): Tuscan Mira II Fe-SEM. Energy dispersive X-Ray analysis (EDX) (using Tescan Mira II) was used for the compositional analysis of the synthesized nanocatalyst. The weight reduction of the catalysts was analyzed by a simultaneous thermal analyzer, Model: STA503. The BET surface area, pore volume and pore size of the catalysts were measured via the nitrogen adsorption method by the use of a PHS-1020 instrument. The Barret, Joyner, Halenda (BJH) method was used for determining the pore size distribution of the nano-ZnO/expanded perlite and perlite. The decomposition temperature of the complexes was defined by TGA/DTA using 
a Simultaneous Thermal Analyzer, Model: STA503 thermogeravimetric analyzer. The crystallite size of the nanocatalysts was estimated from the Debye-Sherrer equation [15]. The iodometric method was used to determine the concentration of gaseous and aqueous ozone [11]. The spectra of aqueous RB5 and by-products of the reaction was determined using UV-vis spectrophotometry (Perkin Elmer, Lambda 25 UV-vis (K-2600)) at a wavelength of 200-700 $\mathrm{nm}$. The removal of color and aromatic fraction of the RB5 solution was determined by the measurement of absorbance at $583 \mathrm{~nm}$ and $312 \mathrm{~nm}$, respectively. The color removal efficiency was calculated as follows:

$$
\text { Color Removal }(\%)=\left(1-\frac{A_{t}}{A_{0}}\right) \times 100
$$

where $A_{t}$ and $A_{0}$ are the absorbances for the dye at reaction time $\mathrm{t}$ and 0 , respectively. The RB5 mineralization was determined by the analysis of the TOC (Shimadzu, TOC-VCSH).

To investigate the kinetic model in the degradation of RB5, the kinetic data for the RB5 and the aromatic fraction removals were correlated with the first-order (Eq. (2)) and the second-order (Eq. (3)) kinetic model [31]:

$$
\begin{aligned}
& \operatorname{Ln}\left(\frac{A_{t}}{A_{0}}\right)=-k_{1} \cdot t \text { First-order kinetic model } \\
& \frac{1}{A_{t}}-\frac{1}{A_{0}}=k_{2} \cdot t \text { Second-order kinetic model }
\end{aligned}
$$

where $A_{0}$ and $A_{t}$ are the absorbances for dye at time 0 and $\mathrm{t}$, respectively; $k_{1}\left(\mathrm{~min}^{-1}\right)$ and $k_{2}$ (A.min) $)^{-1}$ are the first-order and the second-order kinetic rate constants, respectively.

\section{Results and Discussion}

\subsection{Catalyst Characterization}

The zinc methionine complex was prepared via the sonochemical method, which was followed by the impregnation for the synthesis of nano-ZnO/perlite. The FTIR spectra of perlite, expanded perlite, and $\mathrm{Zn}$ (methionine)/expanded perlite samples were taken in the $400-4,000 \mathrm{~cm}^{-1}$ range (Fig. S2). The results showed that vibrational bands of about $2,101 \mathrm{~cm}^{-1}$, due to the vibration of $\mathrm{NH}_{3}{ }^{+}$, did

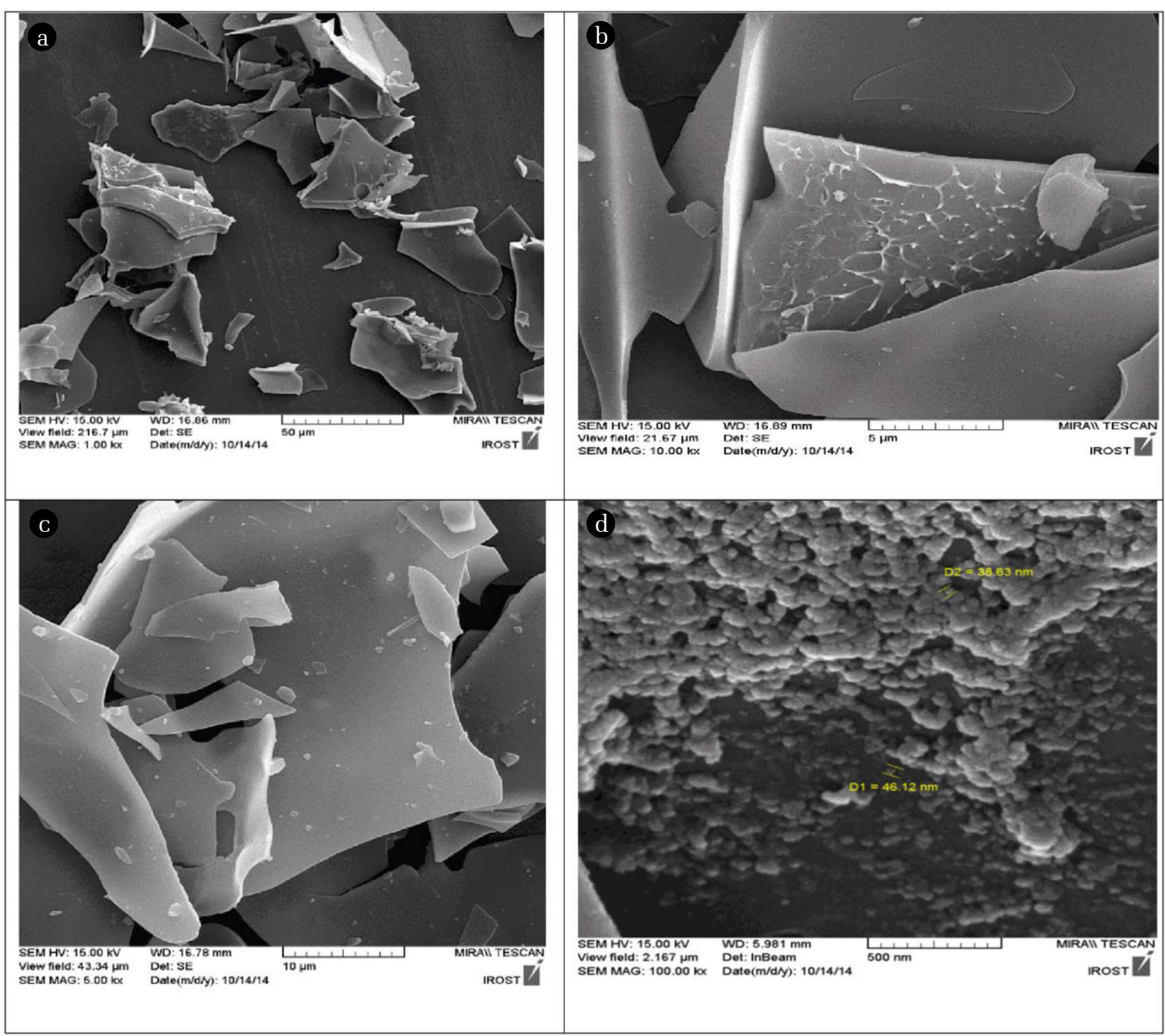

Fig. 1. FESEM images of (a) perlite (low magnification) (b) perlite (high magnification) (c) expanded perlite (d) ZnO/expanded-perlite nanocatalyst. 
Table 1. Pore Volume, Pore Size and Specific Surface Area of Perlite and ZnO/Expanded Perlite Nanocatalyst

\begin{tabular}{|c|c|c|c|}
\hline Material & Pore volume $\left(\mathrm{cm}^{3} \mathrm{~g}^{-1}\right)$ & Average pore size (nm) & Specific surface area $\left(\mathrm{m}^{2} \mathrm{~g}^{-1}\right)$ \\
\hline $\mathrm{ZnO} /$ expanded perlite & 0.397 & 2.345 & 145.154 \\
\hline perlite & 0.377 & 2.315 & 116.980 \\
\hline
\end{tabular}

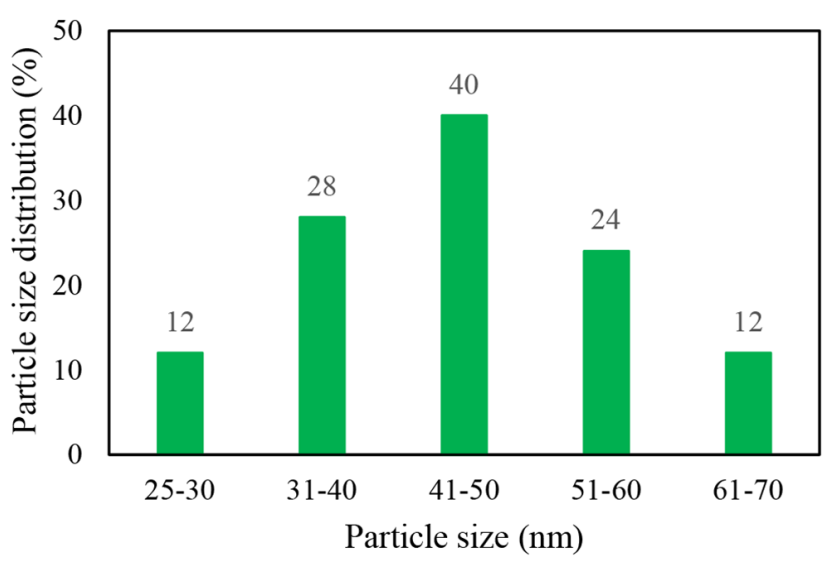

Fig. 2. Size distribution of synthesized nanocatalyst.

not exist in the spectrum. The sharp bands of $1,580 \mathrm{~cm}^{-1}$ were related to the stretching vibration of $\mathrm{C}=\mathrm{O}$ for free methionine, which after the coordination of the $\mathrm{C}=\mathrm{O}$ group to a metal ion, the vibrational bands shifted to an upper frequency $\left(1,630 \mathrm{~cm}^{-1}\right)$ [32]. The bands shifted towards higher or lower frequencies due to the coordination bonds around the $\mathrm{Zn}(\mathrm{II})$ and methionine ligand. The bands 1,390 vas (COO) $\mathrm{cm}^{-1}, 1,600$ vst $(\mathrm{C}=\mathrm{O}) \mathrm{cm}^{-1}, 1,500$ vb $\left(\mathrm{NH}_{2}\right) \mathrm{cm}^{-1}$, and $3,500,3,324$ and $3,450 \mathrm{~cm}^{-1}$ vst $\left(\mathrm{NH}_{2}\right)$ were seen and assigned to the synthesis of the $\left[\mathrm{Zn} \mathrm{C}_{4} \mathrm{H}_{9} \mathrm{SNH}_{2} \mathrm{COOH}\right]$ complex on the perlite. The bands shifted towards higher or lower frequencies due to the coordination bonds around the $\mathrm{Zn}$ (II) and methionine ligand.

The FESEM images of the products are shown in Fig. 1. Fig. 1(d) shows that the nanocatalysts were synthesized homogeneously onto the perlite sheets. The average size of the $\mathrm{ZnO}$ nanoparticle was $41-50 \mathrm{~nm}$ (Fig. 2). It is obvious that the activity and selectivity of the catalyst depends on the metal/metal oxide particle size [17].

The EDX analysis of the nano-ZnO/expanded perlite is illustrated in Fig. 3. As Fig. S3 shows, the presence of zinc in the EDX spectra indicates the formation and immobilization of $\mathrm{Zn}$ on the perlite. The nitrogen adsorption/desorption isotherm of perlite and the synthesized catalyst is of type III according to IUPAC classification (Fig. S4). The BJH method was used to determine the pore size distribution of the nano- $\mathrm{ZnO} /$ expanded perlite and perlite. The pore characteristics of perlite and $\mathrm{n}-\mathrm{ZnO} /$ expanded perlite are shown in Table 1. The surface area of perlite and nano- $\mathrm{ZnO} /$ expanded perlite were measured by the BET method, which were 116.98 and $145.154 \mathrm{~m}^{2} \mathrm{~g}^{-1}$ respectively. The results showed the immobilization of $\mathrm{ZnO}$ nanoparticles onto the perlite support.

\subsection{Color Removal of RB5 in a Bubble Column Slurry Reactor}

The semi-batch color removal of RB5 in aqueous solution (100 $\mathrm{mg} \mathrm{L}^{-1}$ ) was investigated by catalytic ozonation using a synthesized

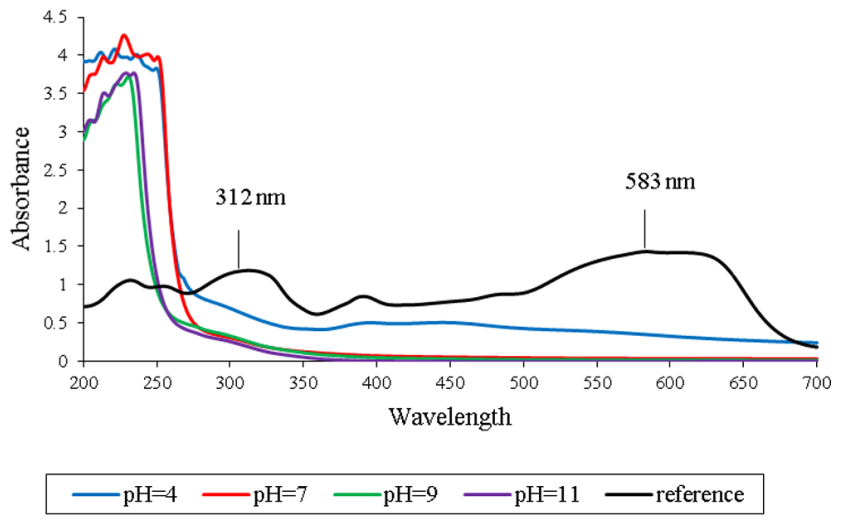

Fig. 3. Decolorization of RB5 by single ozonation at different $\mathrm{pHs}$; RB5 conc.:100 mg L ${ }^{-1}$, reaction time: $60 \mathrm{~min}$. The reference line is RB5 dye with no $\mathrm{pH}$ adjustment.

$\mathrm{ZnO} /$ perlite nanocatalyst. The influence of different parameters including $\mathrm{pH}$, reaction time and catalyst dosage was studied. The dye removal percentage was monitored by measuring the absorption peaks of the dye in the visible and UV regions of the spectrum. Fig. 3 depicts two major characteristic peaks at 583 and $312 \mathrm{~nm}$ for RB5. The variation in the absorption peak at $583 \mathrm{~nm}$ in the visible region was used to measure the decolorization of RB5. This is a typical characteristic of the chromophore containing long conjugated $\pi$-system that is linked by two azo-double bond groups of RB5. The absorption peak at $\approx 312 \mathrm{~nm}$ in the UV region is the characteristic peak of naphthalene and benzene rings bonded to the $-\mathrm{N}=\mathrm{N}-$ group [33]. Fig. 3 shows the effect of single ozone on the reduction of the two characteristics peaks of RB5 at different pH levels. The generation of the peaks in lower wavelengths shows the production of by-products of the ozonation process. A high removal of RB5 color (i.e. 583 $\mathrm{nm}$ ) is seen because ozonation is an effective process for dye decolorization due to its attack on the conjugated double bonds that are often associated with the color in the dye molecule [16].It has been reported that the azo group, $(-\mathrm{N}=\mathrm{N}-)$, is the most active site to be oxidized either by an $\mathrm{OH}$-radical or ozone [34].

\subsubsection{Effect of $\mathrm{pH}$ on RB5 degradation}

The influence of the $\mathrm{pH}$ of the dye solution on RB5 removal was studied at three pH levels, 7, 9 and 11, by single ozonation and catalytic ozonation. The lower $\mathrm{pH}$ value of 4 was also investigated by single ozonation, which showed low color removal (66.5\%) of RB5 after $60 \mathrm{~min}$. Moreover, the preliminary tests showed that there was not any changes in RB5 removal at pH values higher than 11 . Therefore, these acidic and basic $\mathrm{pHs}$ were not considered for the further studies. The degradation of both the aromatic fraction and color of dye was investigated for $60 \mathrm{~min}$ (Fig. 4). The initial removal rate of dye fractions was 


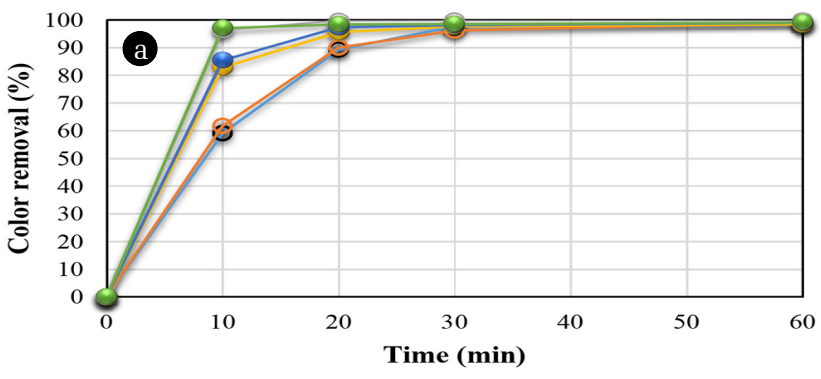

$$
\begin{array}{lll}
-0-\text { Ozone, } \mathrm{pH} 7 & - \text { Ozone, } \mathrm{pH} 9 & -0 \text { Ozone, } \mathrm{pH} 11 \\
-0 \text { Ozone-Cat,pH7 } & - \text { - Ozone-Cat, } \mathrm{pH} 9 & - \text { - Ozone-cat,pH11 }
\end{array}
$$

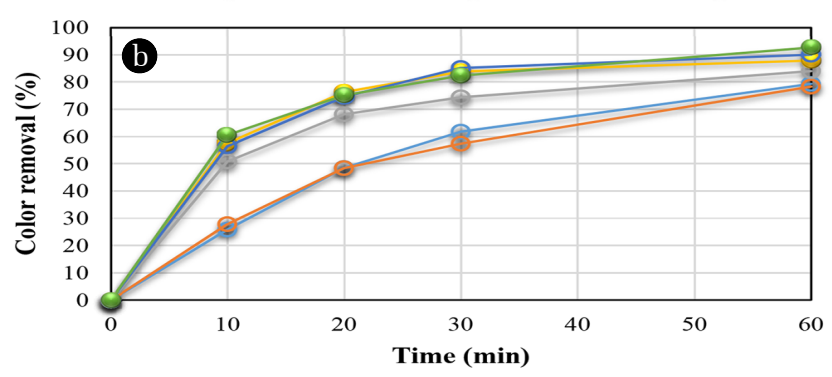

-Ozone, $\mathrm{pH} 7 \quad 0$ Ozone, $\mathrm{pH} 9 \quad 0$ Ozone, pH11 -Ozone-Cat, pH7 -Ozone-Cat,pH9 - Ozone-cat,pH11

Fig. 4. The removal of RB5 dye color (a) and its aromatic fraction (b) at different $\mathrm{pHs}$ by ozonation and catalytic ozonation. Initial RB5 concentration: $100 \mathrm{mg} \mathrm{L}^{-1}$; catalyst dosage: $12 \mathrm{~g} \mathrm{~L}^{-1}$.

further improved by the introduction of the catalyst, especially at lower pHs, indicating that an extra reaction pathway was introduced for dye fraction decay. Two pathways, namely direct oxidation by molecular ozone and oxidation by hydroxyl radicals, were generated by the decomposition of ozone molecules in water via ozonation in aqueous solutions. The use of higher $\mathrm{pH}$ values and the application of AOP processes can produce a higher concentration of hydroxyl radicals [16].

The results showed that higher $\mathrm{pH}$ values favored the removal of RB5 dye during single ozonation. The mechanism of reaction was a direct ozone attack on the $\mathrm{C}$ double bonds in chromophoric molecules leading to the formation of decolored intermediate products. The RB5 color removal was increased by increasing the $\mathrm{pH}$ value, which was due to the enhancing of $\mathrm{OH}$ radical production. The application of AOPs at higher $\mathrm{pH}$ values can produce higher concentrations of hydroxyl radicals [16]. In this regard, more alkaline conditions $(\mathrm{pH}=11)$ showed higher color removal at each time interval. Although the RB5 color was eliminated by single ozonation at a $\mathrm{pH}$ of 11 after $60 \mathrm{~min}$, about $82 \%$ of the aromatic fraction of the RB5 was degraded at this $\mathrm{pH}$ value (Fig. 4).

The use of the $\mathrm{ZnO} /$ perlite nanocatalyst in catalytic ozonation enhanced the rate of color removal for all pHs by acceleration of the catalytic decomposition of ozone on the active sites of the applied nanocatalyst [35, 36], even though the impact of $\mathrm{pH}$ generally depends on the nature of the catalyst [37]. It is shown by quantum-chemistry calculations that the electron density distribution on the atoms of $\mathrm{ZnO}$ catalyst is important in degradation properties of the catalyst. The charge density of the catalyst surface may vary by $\mathrm{pH}$ changes
[38]. There is no big difference between single ozonation and catalytic ozonation at a high $\mathrm{pH}$ of 11 in color removal, however, the removal of the aromatic fraction of the dye is meaningful after $60 \mathrm{~min}$ (90\% compared to $82 \%$ ). This result revealed a higher cleavage rate of aromatic bonds by ozonation in the presence of the synthesized nanocatalyst and showed that the cleavage of the azo groups of the RB5 molecule was much easier than the degradation of decolorization by-products [39].

\subsubsection{Kinetics of dye removal by catalytic ozonation}

The removal of RB5 in aqueous solution was enhanced with an increase in reaction time in both the single ozonation and $\mathrm{O}_{3}$-nano-ZnO/perlite processes. The color removal was increased by increasing the contact time up to $30 \mathrm{~min}$ for all $\mathrm{pH}$ values, which showed the progress of the oxidation process (Fig. 4). In catalytic ozonation, a higher degradation kinetics of RB5 was observed, especially at lower $\mathrm{pH}$ values compared to the single ozonation. The higher kinetic constants of dye oxidation by $\mathrm{OH}$-radical reaction compared to the ozone, resulted in the rapid degradation of RB5 [31].

The use of the nanocatalyst resulted in higher kinetics of the degradation of RB5 at low pHs. A dye removal of 43.5 and $43.6 \%$ was observed after $10 \mathrm{~min}$ at a $\mathrm{pH}$ of 7 and 9 in single ozonation, respectively, while a 76.6 and $81 \%$ dye removal was measured for catalytic ozonation. At the same time, 10 and 18\% of aromatic fraction (for single ozonation) and 50.3 and $52 \%$ (for catalytic ozonation) was removed from the solution at a $\mathrm{pH}$ of 7 and 9, respectively (Fig. 4). It showed the higher resistance of aromatic fraction for decay by the single ozone [37]. The existence of the nanocatalyst accelerated the decay kinetics. More than $96 \%$ of the initial color and $58 \%$ of the aromatic fraction of the RB5 was eliminated during $10 \mathrm{~min}$ at a $\mathrm{pH}=11$ in catalytic ozonation. The analogous values for single ozonation were $93 \%$ and $43 \%$, respectively. The difference between dye removals by both methods was insignificant at a $\mathrm{pH}$ of 11 , where oxidation by the $\mathrm{OH}$-radical was the dominant process.

The results also demonstrated that the dye color was completely removed by single ozonation at higher reaction times; however, the dye degradation kinetics was enhanced by applying the

Table 2. The First-order and Second-order Rate Constants for the Decolorization and Removal of Aromatic Fraction of the RB5 Dye in Catalytic Ozonation Using Synthesized ZnO/Perlite Nanocatalyst in Different Initial pHs; Initial RB5 Conc.: 100

\begin{tabular}{|c|c|c|c|c|}
\hline pH & $\mathbf{R}^{2}$ & $\begin{array}{c}k_{1} \\
\left(\min ^{-1}\right)\end{array}$ & $\mathbf{R}^{2}$ & $\begin{array}{c}k_{2} \\
\left(\mathrm{au}^{*} \cdot \mathrm{min}\right)^{-1}\end{array}$ \\
\hline \multicolumn{5}{|c|}{ Color removal } \\
\hline 7 & 0.7418 & 0.043 & 0.9397 & 1.219 \\
\hline 9 & 0.7221 & 0.046 & 0.9694 & 1.131 \\
\hline 11 & 0.8812 & 0.0219 & 0.9756 & 1.333 \\
\hline \multicolumn{5}{|c|}{ Aromatic frac. removal } \\
\hline 7 & 0.7616 & 0.023 & 0.9263 & 0.096 \\
\hline 9 & 0.8721 & 0.028 & 0.9626 & 0.131 \\
\hline 11 & 0.9897 & 0.033 & 0.9841 & 0.194 \\
\hline
\end{tabular}
$\mathrm{mg} \mathrm{L}^{-1}$; Catalyst Dosage: $12 \mathrm{~g} \mathrm{~L}^{-1}$ 
nanocatalysts. This phenomenon reduced the consumption of ozone in the wastewater treatment processes.

The first- and second-order kinetic models were fitted to the experimental data for the degradation of color and aromatic fractions of RB5 dye at three levels of $\mathrm{pH}$. The results are plotted in Fig. S5. Table 2 presents the kinetic data of the catalytic ozonation. It shows that the first-order model did not represent a good fit to the experiments. The second-order kinetics showed higher correlation coefficients $\left(\mathrm{R}^{2}\right)$ and better fitting in terms of both RB5 color removal and the degradation of the aromatic fraction of the solution. Furthermore, the $k_{2}$ rate constants for the second-order kinetic model for both RB5 color and aromatic fraction removals increased with the increase in the initial $\mathrm{pH}$ values of the solution.

\subsubsection{Effect of catalyst dosage}

Dye removal as a function of catalyst dosage in the range of 8-20 $\mathrm{g} \mathrm{L}^{-1}$ is presented in Fig. S6. A higher catalyst dosage causes an increase in the removal of RB5 due to its influence in the $\mathrm{OH}$ - radical generation through catalyst active sites. The surface area and active sites are two important factors which influences color removal [12]. A higher catalyst dose provides more active sites for the catalytic reactions. Other researchers also reported a positive effect as a result of increasing the catalyst dosage that is advantageous for the elimination of organic pollutant $[6,40]$. The catalyst dosage of $8 \mathrm{~g} \mathrm{~L}^{-1}$ resulted in high RB5 decolorination (94\%), while a further increase in the amount of nanocatalyst improved the value to $100 \%$. At a catalyst dosage of $20 \mathrm{~g} \mathrm{~L}^{-1}$, an improvement in the aromatic fraction removal from 52 to $72 \%$ was seen; this was likely due to the cleavage of the aromatic rings of the dye. It is suggested that increasing the nanocatalyst amount with high surface area caused an increase in the number of active sites on the surface of the nanocatalyst. This then led to higher rates of OH-radical production, which improved the removal rates of the color and aromatic fraction of RB5.

\subsubsection{Mineralization of RB5}

The TOC was measured to assess the degree of dye mineralization [40]. The TOC values of the dye solution after single ozonation at different $\mathrm{pHs}$ are presented in Table 3. The mineralization of the dye improved $34 \%$ by increasing the $\mathrm{pH}$ after $60 \mathrm{~min}$. This means that the contribution of OH-radicals in RB5 oxidation increased at a high $\mathrm{pH}$. The addition of the nanocatalyst increased the rate of mineralization, so that at a lower contact time (i.e., $10 \mathrm{~min}$ ), 35\% and 47\% mineralization improvement compared to single ozonation was achieved by the use of 12 and $20 \mathrm{~g} \mathrm{~L}^{-1}$ catalyst at $\mathrm{pH} 11$, respectively. The same trend in TOC removal of dye solution was reported by other researchers for Fe-Mn oxides loaded on granular activated carbon [5]. The data presented in Table 4 demonstrates that the application of the nanocatalyst almost doubled the mineralization of the dye, while the degradation of the dye did not show a big difference between single ozonation and catalytic ozonation (see Fig. 4). Therefore, consequent oxidation of the intermediates, resulting from the RB5 cleavage, was achieved by the synthesized nanocatalyst. Other studies have also shown that direct mineralization of refractory intermediates by ozone was low [41]. The active sites caused
Table 3. Mineralization Degree of RB5 Dye Solution by Single Ozonation, $\mathrm{t}=60 \mathrm{~min}$, Dye Concentration: $100 \mathrm{mg} \mathrm{L}^{-1}$; Initial TOC $=31.45 \mathrm{mg} \mathrm{L}^{-1}$, Catalyst Dosage: $12 \mathrm{mg} \mathrm{L}^{-1}$

\begin{tabular}{lcc}
\hline $\mathbf{p H}$ & TOC $\left(\mathbf{m g ~ L}^{-\mathbf{1}}\right)$ & TOC reduction $\mathbf{( \% )}$ \\
\hline 7 & 21.2 & 32.6 \\
9 & 17.2 & 45.3 \\
11 & 15.9 & 49.3 \\
\hline
\end{tabular}

Table 4. Comparison of TOC Reduction of RB5 Dye Solution by Single Ozonation and Nanocatalyst/Ozonation after $10 \mathrm{~min}$, Dye Concentration: $100 \mathrm{mg} \mathrm{L}^{-1} ; \mathrm{pH}=11$, Initial $\mathrm{TOC}=31.45$ $\mathrm{mg} \mathrm{L}^{-1}$

\begin{tabular}{lcc}
\hline Conditions & $\begin{array}{c}\text { TOC } \\
\left(\mathbf{m g ~ L}^{-\mathbf{1}}\right)\end{array}$ & $\begin{array}{c}\text { TOC reduction } \\
\mathbf{( \% )}\end{array}$ \\
\hline Single ozonation & 23.0 & 26.9 \\
Ozonation/nanocatalyst $\left(12 \mathrm{~g} \mathrm{~L}^{-1}\right)$ & 18.5 & 41.2 \\
Ozonation/nanocatalyst $\left(20 \mathrm{~g} \mathrm{~L}^{-1}\right)$ & 15.6 & 50.5 \\
\hline
\end{tabular}

an increase in the concentration of the $\mathrm{OH}$ radical. They acted as a position for the reaction between intermediate compounds to be mineralized.

\section{Conclusions}

A $\mathrm{ZnO} /$ expanded perlite nanocatalyst was synthesized successfully using a methionine precursor and the sonochemical method. This synthesis method resulted in a uniform size distribution of around 41-50 $\mathrm{nm}$. The experimental results revealed that the synthesized $\mathrm{ZnO}$ /perlite nanocatalyst degraded the aromatic fraction of the RB5 molecule more than the single ozonation. However, single ozonation at a higher contact time and $\mathrm{pH}$ values successfully removed dye color from the solution. Also, the nano-ZnO/perlite showed relatively high dye removal at a lower contact time and neutral $\mathrm{pH}$. Therefore, this catalyst can be potentially used for industrial wastewater treatment at its natural $\mathrm{pH}$ The results indicated that the presence of nano- $\mathrm{ZnO} /$ perlite increased the degree of mineralization in a very short time because the nanocatalyst accelerated the generation of $\mathrm{OH}$ radical more easily.

\section{References}

1. Hu E, Wu X, Shang S, Tao XM, Jiang SX, Gan L. Catalytic ozonation of simulated textile dyeing wastewater using mesoporous carbon aerogel supported copper oxide catalyst. J. Clean. Prod. 2016;112:4710-4718.

2. Chang M, Shih Y. Synthesis and application of magnetic iron oxide nanoparticles on the removal of Reactive Black 5: Reaction mechanism, temperature and pH effects. J. Environ. Manage. 2018;224:235-242.

3. Moussavi G, Mahmoudi M. Degradation and biodegradability improvement of the reactive red 198 azo dye using catalytic ozonation with MgO nanocrystals. Chem. Eng. J. 2009;152:1-7. 4. Wang H, Zheng XW, Su JQ, Tian Y, Xiong XJ, Zheng TL. 
Biological decolorization of the reactive dyes Reactive Black 5 by a novel isolated bacterial strain Enterobacter sp. EC3. J. Hazard. Mater. 2009;171:654-659.

5. Tang S, Yuan D, Zhang Q, et al. Fe-Mn bi-metallic oxides loaded on granular activated carbon to enhance dye removal by catalytic ozonation. Environ. Sci. Pollut. Res. 2016;23: 18800-18808.

6. Beltrán F, Rivas F, Ramón M. Catalytic ozonation of oxalic acid in an aqueous $\mathrm{TiO}_{2}$ slurry reactor. Appl. Catal. B- Environ. 2002;39:221-231.

7. Beltrán FJ, Rivas FJ, Montero-De-Espinosa R. Iron type catalysts for the ozonation of oxalic acid in water. Water Res. 2005;39:3553-3564.

8. Liu ZQ, Ma J, Cui YH. Carbon nanotube supported platinum catalysts for the ozonation of oxalic acid in aqueous solutions. Carbon 2008;46:890-897.

9. Ni CH, Chen JN. Heterogeneous catalytic ozonation of 2-chlorophenol queous solution with alumina as a catalyst. Water Sci. Technol. 2001;43:213-220.

10. Zhang $\mathrm{F}$, Wu K, Zhou $\mathrm{H}$, et al. Ozonation of aqueous phenol catalyzed by biochar produced from sludge obtained in the treatment of coking wastewater. J. Environ. Manage. 2018;224: 376-386.

11. He K, Dong Y, Yin L, Zhang A, Li Z. A facile hydrothermal method to synthesize nanosized $\mathrm{Co}_{3} \mathrm{O}_{4} / \mathrm{CeO}_{2}$ and study of its catalytic characteristic in catalytic ozonation of phenol. Catal. Lett. 2009;133:209-213.

12. Pugazhenthiran N, Sathishkumar P. Effective degradation of acid orange 10 by catalytic ozonation in the presence of $\mathrm{Au}-\mathrm{Bi}_{2} \mathrm{O}_{3}$ nanoparticles. Chem. Eng. J. 2011;168:1227-1233.

13. Qin W, Li X, Qi J. Experimental and theoretical investigation of the catalytic ozonation on the surface of $\mathrm{NiO}-\mathrm{CuO}$ nanoparticles. Langmuir 2010;25:8001-8011.

14. Ikhlaq A, Brown DR, Kasprzyk-Hordern B. Catalytic ozonation for the removal of organic contaminants in water on ZSM-5 zeolites. Appl. Catal. B- Environ. 2014;154-155:110-122.

15. Manivel A, Lee GJ, Chen CY, et al. Synthesis of $\mathrm{MoO}_{3}$ nanoparticles for azo dye degradation by catalytic ozonation. Mater. Res. Bull. 2015;62:184-191.

16. Pirgalioğlu S, Özbelge TA. Comparison of non-catalytic and catalytic ozonation processes of three different aqueous single dye solutions with respect to powder copper sulfide catalyst. Appl. Catal.- A Gen. 2009;363:157-163.

17. Huang WJ, Fang GC, Wang CC. A nanometer-ZnO catalyst to enhance the ozonation of 2, 4, 6-trichlorophenol in water. Colloid. Surf. A: Physicochem. Eng. Asp. 2005;260:45-51.

18. Chaudhary S, Kaur Y, Umar A, Chaudhary GR. 1-butyl-3-methylimidazolium tetrafluoroborate functionalized $\mathrm{ZnO}$ nanoparticles for removal of toxic organic dyes. J. Mol. Liq. 2016;220:1013-1021.

19. Oskoei V, Dehghani MH, Nazmara S, et al. Removal of humic acid from aqueous solution using UV/ZnO nano-photocatalysis and adsorption. J. Mol. Liq. 2015;213:374-380.

20. Sathe P, Myint MTZ, Dobretsov S, Dutta J. Removal and regrowth inhibition of microalgae using visible light photocatalysis with ZnO nanorods: A green technology. Sep. Purif. Technol. 2016;162:61-67.
21. Hong R, Pan T, Qian J, Li H. Synthesis and surface modification of ZnO nanoparticles. Chem. Eng. J. 2006;119:71-81.

22. Zhou Y, Xia C, Hu X, et al. Dye-sensitized solar cells based on nanoparticle-decorated $\mathrm{ZnO} / \mathrm{SnO}_{2}$ core/shell nanoneedle arrays. Appl. Surf. Sci. 2014;292:111-116.

23. Mohaghegh N, Tasviri M, Rahimi E, Gholami MR. Nano sized ZnO composites: Preparation, characterization and application as photocatalysts for degradation of AB92 azo dye. Mater. Sci. Semicond. Process. 2014;21:167-179.

24. Hayat K, Gondal MA, Khaled MM, Ahmed S, Shemsi AM. Nano ZnO synthesis by modified sol gel method and its application in heterogeneous photocatalytic removal of phenol from water. Appl. Catal.- A Gen. 2011;393:122-129.

25. Chrissanthopoulos A, Kyriazis FC, Nikolakis V, et al. ZnO/zeolite hybrid nanostructures: Synthesis, structure, optical properties, and simulation. Thin Solid Films 2014;555:21-27.

26. Bouvy C, Marine W, Sporken R, Su BL. Nanosized ZnO confined inside a Faujasite $\mathrm{X}$ zeolite matrix: Characterization and optical properties. Colloid. Surf. A- Physicochem. Eng. Asp. 2007;300:145-149.

27. Kiomarsipour N, Razavi RS. Superlattices and microstructures characterization and optical property of $\mathrm{ZnO}$ nano-, submicroand microrods synthesized by hydrothermal method on a large-scale. Superlatt. Microstruct. 2012;52:704-710.

28. He W, Zhao H, Jia H, Yin JJ, Zheng Z. Determination of reactive oxygen species from $\mathrm{ZnO}$ micro-nano structures with shape-dependent photocatalytic activity. Mater. Res. Bull. 2014;53:246-250.

29. Wang Y, Yang Y, Xi L, et al. A simple hydrothermal synthesis of flower-like $\mathrm{ZnO}$ microspheres and their improved photocatalytic activity. Mater. Lett. 2016;180:55-58.

30. Radosavljevic-Mihajlovic A, Dondur V, Daković A, Lemić J, Tomašević-Čanović M. Physicochemical and structural characteristics of HEU-type zeolitic tuff treated by hydrochloric acid. J. Serb. Chem. Soc. 2004;69:273-281.

31. Chen CY, Cheng MC, Chen AH. Photocatalytic decolorization of Remazol Black 5 and Remazol Brilliant Orange 3R by mesoporous $\mathrm{TiO}_{2}$. J. Environ. Manage. 2012;102:125-133.

32. Al-jeboori FHA, Al-shimiesawi TAM, Mohammed O, Jassim N. Synthesis and characterization of some essential amino acid metal complexes having biological activity. J. Chem. Pharma. Res. 2013;5:172-176.

33. Weng CH, Lin YT, Yuan HM. Rapid decoloration of Reactive Black 5 by an advanced Fenton process in conjunction with ultrasound. Sep. Purif. Technol. 2013;117:75-82.

34. Khataee AR, Pons MN, Zahraa O. Photocatalytic degradation of three azo dyes using immobilized $\mathrm{TiO}_{2}$ nanoparticles on glass plates activated by UV light irradiation: Influence of dye molecular structure. J. Hazard. Mater. 2009;168:451-457.

35. Sun Q, Li L, Yan H, Hong X, Hui KS, Pan Z. Influence of the surface hydroxyl groups of $\mathrm{MnOx} / \mathrm{SBA}-15$ on heterogeneous catalytic ozonation of oxalic acid. Chem. Eng. J. 2014;242:348-356.

36. Ikhlaq A, Brown DR, Kasprzyk-Hordern B. Mechanisms of catalytic ozonation on alumina and zeolites in water:formatin of hydroxyl radicals. Appl. Catal. B- Environ. 2012;123-124: 94-106. 
37. Mahmoodi NM. Photocatalytic ozonation of dyes using multiwalled carbon nanotube. J. Mol. Catal.-A Chem. 2013;366: 254-260.

38. Turkay O, Inan H, Dimoglo A. Experimental and theoretical study on catalytic ozonation of humic acid by $\mathrm{ZnO}$ catalyst. Sep. Sci. Technol. 2017;52:778-786.

39. Zhang T, Li WW, Croue JP. Catalytic ozonation of oxalate with a cerium supported palladium oxide: An efficient degradation not relying on hydroxyl radicals oxidation. Environ.
Sci. Technol. 2011;45:9339-9346.

40. Gao G, Shen J, Chu W, Chen Z, Yuan L. Mechanism of enhanced diclofenac mineralization by catalytic ozonation over iron silicate-loaded pumice. Sep. Purif. Technol. 2017;173:55-62.

41. Venkatesh S, Quaff AR, Pandey ND, Venkatesh K. Impact of ozonation on decolorization and mineralization of azo dyes: Biodegradability enhancement, by-Products formation, required energy and cost. Ozone Sci. Eng. 2015;37:420-430. 